\title{
Should Courts Consider 18 USC § 3501 Sua Sponte?
}

\author{
Eric D. Miller $\dagger$
}

In the landmark case of Miranda $v$ Arizona, ${ }^{1}$ the Supreme Court declared that police must advise a criminal suspect of certain constitutional rights before questioning him. ${ }^{2}$ Two years later, Congress responded by enacting a statute providing that in federal cases, police need not issue Miranda warnings before questioning a suspect. Under the statute, 18 USC \& 3501, the constitutionality of the interrogation (and the subsequent admissibility of any confession) depends instead on whether or not the suspect made the statements "voluntarily," as measured by the totality of the circumstances. ${ }^{3}$

The statute's enactment could have led to a conflict between Congress and the Court, perhaps culminating in a judicial determination of the statute's validity. Instead, Section 3501 has been virtually ignored in the thirty years since its enactment. The Justice Department generally has not invoked it in criminal prosecutions. Nor have courts considered the issues that it poses. Instead, they have continued to decide cases in accordance with Miranda.

Still, Section 3501 might not be destined for eternal dormancy. In a recent concurring opinion, Justice Scalia argued that courts should take up Section 3501 sua sponte. ${ }^{4}$ The majority of the Court was not receptive to his suggestion and expressed reluctance to consider the statute given the Justice Department's refusal to invoke it. ${ }^{5}$ Nevertheless, Justice Scalia's proposal has called new attention to the statute and may influence future courts' consideration of the issue.

This Comment contends that Justice Scalia is right-courts should consider Section 3501 sua sponte. It surveys the scope of the judicial power to consider issues sua sponte, classifies the jus-

$\dagger$ A.B. 1996, Harvard University; J.D. Candidate 1999, The University of Chicago.

384 US 436 (1966).

2 Id at 467-73.

3 Omnibus Crime Control and Safe Streets Act of 1968, Title II § 701(a), Pub L No 90351, 82 Stat 210, codified at 18 USC $\$ 3501$ (1994).

1 Davis $v$ United States, 512 US 452, 462 (1994) (Scalia concurring).

- Id at $457 n *$ (majority opinion). 
tifications for the exercise of the power, and acknowledges the prudential concerns that often counsel against its exercise. In analyzing Section 3501, this Comment pays special attention to an additional element implicated here but not usually present in cases involving sua sponte consideration: the doctrine of separation of powers.

Part I introduces the history of Miranda and Section 3501, describing the statute's enactment and its history of nonimplementation. Part II surveys the central cases that discuss the power of courts to consider arguments not raised by parties. It then examines, in three different contexts, the arguments supporting the exercise of this power and the prudential concerns that counsel against it. Part III applies this analysis to Section 3501 and concludes that courts should consider the statute sua sponte. Finally, Part IV analyzes the prosecutorial discretion and separation of powers issues that are relevant in the Section 3501 context. It determines that, notwithstanding these separation of powers concerns, courts should consider the statute sua sponte.

\section{Miranda, CONGRESS, AND THE DEPARTMENT OF JUSTICE}

A. Miranda and Congressional Reaction

During the 1960s, the Supreme Court constitutionalized much of the law of criminal procedure, creating several rules to protect the constitutional rights of criminal suspects. In 1964, the Court held in Escobedo $v$ Illinois, ${ }^{6}$ that when a police investigation "is no longer a general inquiry into an unsolved crime but has begun to focus on a particular suspect," the suspect has a Sixth Amendment right to consult with an attorney before custodial interrogation. ${ }^{7}$ If the suspect requests counsel and his request is refused, then any statement he makes is inadmissible at trial. ${ }^{8}$

Two years later, in Miranda $v$ Arizona, the Court extended the rule of Escobedo, holding that suspects must be informed of their pretrial procedural rights. ${ }^{9}$ The Court was concerned that

without proper safeguards the process of in-custody interrogation . . . contains inherently compelling pressures which work to undermine the individual's will to resist and to compel him to speak where he would otherwise not do so freely.

6 378 US 478 (1964).

7 Id at $490-91$.

- Id at 491.

- 384 US at 467-73. 
In order to combat these pressures and to permit a full opportunity to exercise the privilege against self-incrimination, the accused must be adequately and effectively apprised of his rights and the exercise of those rights must be fully honored. ${ }^{10}$

Accordingly, police are required to advise a suspect that he has the right to remain silent, that any statements he makes can and will be used against him in court, and that he has the right to consult with a lawyer, either retained or appointed, and to have the lawyer present during questioning. ${ }^{11}$ If the suspect wishes to remain silent or to consult an attorney, the police must cease questioning him. ${ }^{12} \mathrm{~A}$ suspect may waive his rights and make a statement. However, before the prosecutor may use the statement at trial, she must demonstrate that the suspect received the required warnings and "knowingly and intelligently" waived his rights. ${ }^{13}$

The initial public reaction to Miranda was hostile, largely because many people believed that it hindered effective law enforcement. ${ }^{14}$ In response to Miranda, Congress enacted Section 3501, part of the Omnibus Crime Control and Safe Streets Act of 1968. ${ }^{15}$ Subsection (a) provides: "In any criminal prosecution

${ }^{10}$ Id at 467.

"Id at 467-73.

${ }^{12}$ Id at $473-74$.

${ }^{13}$ Id at 479. This rule applies to the prosecution's case-in-chief. Statements obtained without Miranda warnings may still be admissible for impeachment purposes. See Oregon $v$ Hass, 420 US 714, 722-23 (1975); Harris $v$ New York, 401 US 222, 224-26 (1971).

"See, for example, 113 Cong Rec H 21087 (Aug 2, 1967) (statement of Representative Hebert) ("It is a wonder they can arrest anyone-that the police can arrest anyone-under the rulings of the present Supreme Court."); 113 Cong Rec H 21187-88 (Aug 3, 1967) (statement of Representative Hutchinson) ("Recently our struggle to keep the criminal element under control has been hobbled by judicial decision."). See also Office of Legal Policy, United States Department of Justice, Report to the Attorney General on the Law of Pre-Trial Interrogation 62-63 (1986) (describing studies in which Miranda was found to have decreased the percentage of interrogations resulting in confession). The decision attracted special public attention because it was applied retroactively to defendants who had been interrogated, but not tried, before Miranda was decided. Many of these defendants were freed because their confessions were inadmissible. Id at 64 .

Scholars continue to debate Miranda's effects on law enforcement. Compare Paul G. Cassell, Miranda's Social Costs: An Empirical Reassessment, $90 \mathrm{Nw}$ U L Rev 387, 484 (1996) ("Roughly 28,000 arrests for serious crimes of violence and 79,000 arrests for property crimes slip through the criminal justice system due to Miranda, and almost the same number of cases are disposed of on terms more favorable to defendants."), with Stephen J. Schulhofer, Miranda's Practical Effect: Substantial Benefits and Vanishingly Small Social Costs, $90 \mathrm{Nw}$ U L Rev 500, 547 (1996) ("For all practical purposes, Miranda's empirically detectable net damage to law enforcement is zero.").

${ }^{15}$ Omnibus Crime Control and Safe Streets Act of $1968 \S 701$ (a), Pub L No 90-351, 82 Stat 210 , codified at 18 USC $\S 3501$ (1994). 
brought by the United States or by the District of Columbia, a confession ... shall be admissible in evidence if it is voluntarily given. ${ }^{\text {} 16}$ As enacted, the statute applies only in federal cases. ${ }^{17}$ The trial judge determines whether or not the confession was voluntary, and thus whether or not to admit it. If the judge admits the confession, she must instruct the jury to give it the weight they feel it deserves under the circumstances. ${ }^{18}$

Subsection (b) of the statute conflicts with Miranda. It provides that courts shall determine the voluntariness of confessions based on

all the circumstances surrounding the giving of the confession, including (1) the time elapsing between arrest and arraignment of the defendant making the confession, if it was made after arrest and before arraignment, (2) whether such defendant knew the nature of the offense with which he was charged or of which he was suspected at the time of making the confession, (3) whether or not such defendant was advised or knew that he was not required to make any statement and that any such statement could be used against him, (4) whether or not such defendant had been advised prior to questioning of his right to the assistance of counsel, and (5) whether or not such defendant was without the assistance of counsel when questioned and when giving such confession.

The presence or absence of any of the above-mentioned factors ... need not be conclusive on the issue of voluntariness of the confession. ${ }^{19}$

This totality of the circumstances test eliminates Miranda's bright line rule, which requires the police to advise the suspect of his rights. ${ }^{20}$ Instead, the statute's test resembles the rule that

${ }^{16} 18$ USC $\S 3501$ (a). Subsection (e) defines "confession" as "any confession of guilt of any criminal offense or any self-incriminating statement made or given orally or in writing.” 18 USC \& 3501(e).

${ }^{17}$ A proposed Section 3502 , eliminated from the final version of the act, would have applied to federal review of state cases. See S Rep No 90-1097, 90th Cong, 2d Sess, reprinted in 1968 USCCAN 2112, 2138-39; 114 Cong Rec S 14177 (May 21, 1968).

${ }^{18} 18$ USC \& 3501(a).

1818 USC \& 3501(b) (emphasis added).

${ }^{20}$ Miranda, 384 US at 468-69 ("[W]e will not pause to inquire in individual cases whether the defendant was aware of his rights without a warning being given. Assessments of the knowledge the defendant possessed, based on information as to his age, education, intelligence, or prior contact with authorities, can never be more than speculation; a warning is a clearcut fact."). Note that the statute also eliminates Escobedo's rule excluding statements elicited after the accused requested and was refused an opportunity to consult with counsel. Escobedo, 378 US at 491. 
existed before Miranda. ${ }^{21}$ According to this rule, a confession obtained from a suspect who was not advised of his rights could be admitted as evidence so long as "all the circumstances" indicated that the confession was voluntary. ${ }^{22}$

Congress made no secret of its hope that Section 3501 would undo Miranda. ${ }^{23}$ In opening the Senate debate on the statute, Senator McClellan argued: "The confusion and disarray injected into law enforcement by [Escobedo and Miranda] are deplorable and demoralizing. They have weakened intolerably the force and effect of our criminal laws, and Congress had better do something about it. ${ }^{224}$ While opponents of the bill questioned its constitutionality, ${ }^{25}$ supporters argued that the measure was a valid exercise of Congress's power to design procedural rules for the protection of constitutional rights. ${ }^{26}$ The bill passed both houses of Congress and was signed into law by President Johnson. ${ }^{27}$

\section{B. Implementation of Section 3501}

The supporters of Section 3501 were disappointed by the events that followed the statute's passage. In signing the bill, President Johnson said that he believed the statute could be "interpreted in harmony with the Constitution," and he promised that federal practices would "continue to conform to the Constitu-

21 See, for example, Haynes $v$ Washington, 373 US 503, 513 (1963) ("[W]hether the confession was obtained by coercion or improper inducement can be determined only by an examination of all the attendant circumstances.”).

218 USC \& 3501(b).

2 For a comprehensive account of the history of the statute, see Adam C. Breckenridge, Congress Against the Court 39-94 (Nebraska 1970). See also Mark E. Herrmann, Note, Looking Down from the Hill, $33 \mathrm{Wm} \&$ Mary L Rev 543, 576-86 (1992); Office of Legal Policy, Law of Pre-Trial Interrogation at 64-72 (cited in note 14).

${ }^{24} 114$ Cong Rec S 11201 (May 1, 1968) (statement of Senator McClellan). See also id at 11206 ("It is time for change-time for change in the Supreme Court of the United States. The thrust of the Miranda ruling, if it is not changed, will sweep us into the throes of anarchy and horror.").

${ }^{25}$ See, for example, 114 Cong Rec S 11595 (May 2, 1968) (statement of Senator Morse) (" $[T]$ he Senate is kidding itself if it thinks it can amend the Constitution or the Bill of Rights with this legislation."); 114 Cong Rec S 11740 (May 3, 1968) (statement of Senator Tydings) ("Many of the provisions in Title II, if not all, are little more than an attempt to amend the Constitution by act of Congress.").

23 See S Rep No 90-1097, 90th Cong, 2d Sess, reprinted in 1968 USCCAN 2112, 213742. For analysis of the argument, see text accompanying notes $41-47$.

${ }^{27}$ See Lyndon B. Johnson, Statement by the President Upon Signing the Omnibus Crime Control and Safe Streets Act of 1968 (June 19, 1968), in 1 Pres Pub Papers 725-28 (1968-69). Johnson apparently shared some of Congress's doubts about the constitutionality of Section 3501. Earlier, he had written to Senator Mansfield, urging passage of the bill's gun control and police block grant provisions. He also recommended that the Senator "not encumbe[r] the legislation with provisions raising grave constitutional questions." 114 Cong Rec S 12450 (May 9, 1968) (statement of Senator Mansfield). 
tion. ${ }^{228} \mathrm{He}$ also announced that the FBPs practice of informing suspects of their rights (a practice that existed before Miranda and was noted by the Miranda Court ${ }^{29}$ ) would continue. ${ }^{30}$ Attorney General Ramsey Clark instructed U.S. Attorneys to offer into evidence only confessions that had been obtained in accordance with Miranda. ${ }^{31}$ Thus, the Johnson Administration neither attempted to use the authority granted by the statute nor sought to test the statute's constitutionality.

The Nixon Administration was somewhat more aggressive in attempting to implement the statute. While Attorney General John Mitchell directed investigative agents and attorneys to comply with Miranda, he indicated that government attorneys could invoke Section 3501 where there was only a minor deviation from the Miranda rules. ${ }^{32}$ Under this policy, a few U.S. Attorneys argued that Section 3501 overruled Miranda, but courts generally avoided the issue. ${ }^{33}$ In United States $v$ Crocker, ${ }^{34}$ the Tenth Circuit held that the statute was valid and that, for a confession to be admissible, compliance with Miranda was not necessary. But since Crocker, the Justice Department has made no fur-

23 Johnson, Statement by the President at 727 (cited in note 27).

See 384 US at 483.

${ }^{30}$ Johnson, Statement by the President at 727 (cited in note 27).

${ }^{31}$ See Daniel Gandara, Admissibility of Confessions in Federal Prosecutions, 63 Georgetown L J 305, 311-12 (1974).

32 See United States Department of Justice, Memorandum: Title II of the Omnibus Crime Control and Safe Streets Act of 1968 (1969), reprinted in 115 Cong Rec S 23236-38 (Aug 11, 1969):

Aside from any constitutional issues, therefore, it is impossible to predict how much weight a particular court will give to the absence of any one of the factors mentioned. For this reason, the only safe course for federal investigative agents, and for such United States Attorneys as may have occasion to talk with defendants, is to continue their present practice of giving the full Miranda warnings.

The area where we believe the statute can be effective and where a legitimate constitutional argument can be made is the situation where a voluntary confession is obtained after a less than perfect warning or a less than conclusive waiver, as, for example, where an agent inadvertently fails to fully explain the right to have counsel appointed for an indigent, or a written waiver is not obtained.

${ }^{3}$ See, for example, United States $v$ Vigo, 487 F2d 295, 299 (2d Cir 1973) (declining to determine the constitutionality of Section 3501); Ailsworth $v$ United States, 448 F2d 439, 440 (9th Cir 1971) (same). See also Office of Legal Policy, Law of Pre-Trial Interrogation at 73 (cited in note 14).

${ }^{34} 510$ F2d 1129, 1136-38 (10th Cir 1975) ("[T]he trial court did not err in applying the guidelines of $\S 3501$... in determining the issue of the voluntariness of Crocker's confession."). Interestingly, the court went on to find that there was also "full compliance with the Miranda mandates," indicating that its discussion of Section 3501 was dicta. Id at 1138. 
ther effort to secure a judicial determination of the statute's validity. ${ }^{35}$

Continuing the policy of its predecessors, the Clinton Administration has not used Section 3501 to seek the reversal of Miranda. Instead, it has attempted to avoid judicial consideration of the statute. ${ }^{36}$ While amicus briefs have raised the issue, the Justice Department has successfully prevented judicial consideration of the statute, in some cases by dismissing indictments. ${ }^{37}$ Furthermore, although the statute has been discussed in oral argument before the Supreme Court, questions from the Justices have failed to elicit a statement from Justice Department lawyers regarding the government's position on the issue. ${ }^{38}$

${ }^{3}$ See Office of Legal Policy, Law of Pre-Trial Interrogation at 74 (cited in note 14). The Office of Legal Policy report, prepared during the Reagan Administration, did propose that the Justice Department use Section 3501 to "seek to persuade the Supreme Court to abrogate or overrule the decision in Miranda v Arizona." Id at 96. However, the Administration does not appear to have succeeded in obtaining any court rulings on Section 3501.

* For example, in Cheely $v$ United States, 21 F3d 914 (9th Cir 1994), an interlocutory appeal of a trial court's decision to exclude the defendant's statements to investigators in a capital mail-bombing case, the government's brief made only passing reference to Section 3501. The Ninth Circuit upheld the suppression of Cheely's statements, id at 923, but then issued an order requesting briefing on the question of whether the issue merited en banc rehearing. See Paul G. Cassell, Tossing Out the Law on Confessions, Legal Times 26, 30 (Apr 24, 1995). The government responded with a memorandum opposing further review of the decision. See id.

${ }^{n}$ In United States $v$ Sullivan, 1998 US App LEXIS 4106 (4th Cir), the U.S. Attorney's office invoked Section 3501 in an appeal of a trial court's decision to suppress a defendant's incriminating statements. Acting Solicitor General Walter Dellinger withdrew the brief and submitted a replacement that did not discuss Section 3501. See Paul G. Cassell and Paul D. Kamenar, Another Law Janet Reno Doesn't Like, Wall St J A13 (Aug 27, 1997); Jody Tabner Thayer, The Exclusionary Suggestion?, ABA J 24 (Dec 1997).

In United States $v$ Leong, 1997 US App LEXIS 15480, *11 (4th Cir), the Fourth Circuit rejected the government's argument that the defendant was not in custody for Miranda purposes at the time he made an incriminating statement. In response, the Justice Department moved to dismiss the indictment. The Washington Legal Foundation, however, filed an amicus brief on Section 3501, prompting the court to order the parties to address the statute. The Justice Department argued that Miranda "is a rule that Congress cannot supersede by legislation," so "it would not be appropriate for the lower courts . . . to apply Section 3501 to admit a defendant's statement in a case in which Miranda would require its suppression, or for the Department of Justice to urge the lower courts to do so." Government Won't Defend 1968 Law Designed to Overrule Miranda Decision, 66 USLW 2170 (Sep 23, 1997).

One notable exception to the Justice Department's pattern of success in avoiding consideration of the statute is United States $v$ Rivas-Lopez, 988 F Supp 1424 (D Utah 1997). In this case, the district court accepted the argument of amicus Safe Streets Coalition; the court concluded that Section 3501 was constitutional and applied it to admit the defendant's incriminating statements. Id at 1424, 1435-36.

${ }^{30}$ Consider this discussion from oral argument in United States $v$ Green, 507 US 545 (1993) (cert dismissed after the death of respondent), in which Mr. Roberts represented the United States:

QUESTION: Mr. Roberts, can I ask about a provision that I didn't even know about? Ive been listening to Miranda cases and Edwards cases and Minnick cases for seven 
Why has the Justice Department failed to use a statute that might make it easier to obtain convictions? No administration has explicitly stated its reasons for not enforcing the statute vigorously, but at least two reasons seem plausible. First, government lawyers may believe that the bright line Miranda rules are easier for law enforcement officers to follow than the flexible totality of the circumstances standard of Section $3501 .^{39}$ This desire to give law enforcement officers a clear rule may partially explain the FBI's pre-Miranda policy of advising suspects of their rights.

Second, the government may doubt the constitutionality of Section 3501. Consequently, it may be reluctant to rely on it and

terms now. Why has the United States never cited in any of those cases 18 USC \$ 3501 ? Is there some reason?

MR. ROBERTS: Well, I don't know why it has never been cited.

QUESTION: It's certainly very relevant to this case, very relevant to a lot of other cases. It has never been cited to us.

MR. ROBERTS: Well, we didn't rely on it below in this case, and so we're not in a position to rely upon it here.

...

QUESTION: Well, but don't-does the Government not feel any duty to call the statute to the attention of lower courts?

QUESTION: Or to this Court?

MR. ROBERTS: Im not aware that we have relied on it at any point.

Transcript of Oral Argument in United States v Green, 91-1521, 1992 WL 687878, *18-20.

Justice Scalia's effort to commit the Justice Department to a position on the subject in Davis $v$ United States, 512 US 452 (1994), was similarly unsuccessful. This exchange came after the attorney for the Justice Department took the position that Section 3501 was inapplicable in the context of a court martial, but declined to express an opinion on whether it was relevant to ordinary criminal prosecutions:

QUESTION: I find it extraordinary that you don't take a position on that and haven't taken a position on that for many years. I can't understand. The language of 3501 seems to squarely apply, and the Government just comes in time after time and doesn't take any position on raising 3501, continues to argue Miranda as though there's no statute specifically addressing it?

\section{MR. SEAMON: I-}

QUESTION: Now, today the reason is that this is under the Uniform Code of Military Justice, which we're going to interpret to be stricter on prophylactic results, contrary to everything else I've ever seen, than is civil or civilian criminal procedures. But it seems to me the Government ought to have a position on this.

MR. SEAMON: You may well be right, Justice Scalia.

Transcript of Oral Argument in Davis $v$ United States, 92-1949, 1994 WL 664976, *44-45.

${ }^{3}$ President Johnson seems to have had this view, referring to Section 3501 as "vague and ambiguous." Johnson, Statement by the President at 727 (cited in note 27). 
risk reversal of a conviction. ${ }^{40}$ There is good reason to doubt the constitutionality of the statute. ${ }^{41}$ The Miranda Court stated that "the issues presented are of constitutional dimensions" because they involve Fifth and Sixth Amendment rights, and Congress may not alter constitutional rights through mere legislation. ${ }^{42}$ At the same time, however, the Court also indicated that the rules in Miranda might not be the only acceptable rules for protecting the rights of suspects:

[W] cannot say that the Constitution necessarily requires adherence to any particular solution for the inherent compulsions of the interrogation process as it is presently conducted. Our decision in no way creates a constitutional straitjacket which will handicap sound efforts at reform, nor is it intended to have this effect. We encourage Congress and the States to continue their laudable search for increasingly effective ways of protecting the rights of the individual while promoting efficient enforcement of our criminal laws. ${ }^{43}$

The Senate committee report on Section 3501 cited this passage from Miranda in support of the argument that the statute was a valid response to the Court's call for legislatively devised procedures to protect the rights of suspects. ${ }^{44}$ But the Court made it clear that alternative procedures would be acceptable only if they were "fully as effective as those described above in informing accused persons of their right of silence and in affording a continuous opportunity to exercise it. ${ }^{345}$ The totality of the circumstances rule is the one approach that the Court unambiguously rejected. ${ }^{46}$ Although the Court has subsequently indicated that the procedural safeguards of Miranda are "not themselves rights protected by the Constitution" but are instead "prophylactic stan-

${ }^{40}$ This seems to be a major factor in the Clinton Administration's policy. See note 37.

4 This Comment takes no position on the constitutionality of Section 3501 , which, in any event, has been discussed extensively elsewhere. See Charles A. Wright, Federal Practice and Procedure: Criminal $\$ 76$ at 127 n 26 (West 2d ed 1982), and authorities cited therein. For purposes of this discussion, it is enough to note that there are serious doubts as to the statute's constitutionality.

4284 US at 490.

${ }^{43}$ Id at 467.

4 $\mathrm{S}$ Rep No 90-1097, 90th Cong, 2d Sess, reprinted in 1968 USCCAN 2112, 2137 ( $[$ [T] $]$ he committee feels that Congress, through its power to prescribe rules of evidence in Federal courts, should respond to the majority opinion's invitation to Congress ....").

${ }^{4}$ Miranda, 384 US at 498.

${ }^{45}$ Id at 490 . See also Recent Statute, Title II of the Omnibus Crime Control and Safe Streets Act of 1968, 82 Harv L Rev 1392, 1396 (1969); Wright, Federal Practice $\$ 76$ at 128 (cited in note 41) ("It is one thing to devise alternative safeguards and quite another to provide, as the 1968 legislation does, that no safeguards are needed."). 
dards" to protect constitutional rights, ${ }^{47}$ it does not necessarily follow that Congress may simply eliminate the safeguards.

\section{Justice Scalia's Concurrence in Davis $v$ United States ${ }^{48}$}

After many years of neglect, Section 3501 has recently attracted new attention. In Davis $v$ United States, the Supreme Court held that police officers may continue to interrogate a suspect until he clearly and unambiguously requests counsel; an ambiguous statement, such as "Maybe I should talk to a lawyer," does not require the police to cease questioning. ${ }^{49}$ The majority opinion relied on Miranda and its progeny, but it did not take Section 3501 into account.

Justice Scalia, on the other hand, wrote a concurring opinion devoted to Section 3501, arguing that the Court should consider the statute sua sponte in a future case:

I agree with the Court that it is proper, given the Government's failure to raise the point, to render judgment without taking account of $\S 3501$. But the refusal to consider arguments not raised is a sound prudential practice, rather than a statutory or constitutional mandate, and there are times when prudence dictates the contrary. As far as I am concerned, such a time will have arrived when a case that comes within the terms of this statute is next presented to us. ${ }^{50}$

Justice Scalia offered three arguments for his position. First, he suggested that "the Third Branch's obligation to decide according to the law" creates a duty to consider the statute, which is "a provision of law directed to the courts." Justice Scalia argued that although the executive has the power to nullify criminal laws through failure to prosecute, and to avoid Section 3501 by simply not introducing confessions that the statute makes admissible, it does not have "the right to determine what objections to the admissibility of the confession are valid in law. $\$ 52$ Second, Justice Scalia observed that by refusing to consider Section 3501 sua sponte, courts are forced to consider Miranda issues that might be irrelevant under federal law. ${ }^{53}$ Finally, he argued that the statute's nonenforcement may have led to the ac-

\footnotetext{
${ }^{47}$ Michigan v Tucker, 417 US 433, 444, 445 (1974).

43 512 US 452 (1994).

19 Id at 461-62.

${ }^{\circ}$ Id at 464 (Scalia concurring) (citations omitted).

s1 Id at 465.

32 Id.

${ }^{53} \mathrm{Id}$.
} 
quittal of dangerous felons "during an era of intense national concern about the problem of runaway crime. 554

In a footnote to the majority opinion, the Court explained that it was declining "the invitation of some amici" to consider Section 3501 because the government had not relied on it. $^{55}$ Conceding that it has the power to consider arguments raised only in an amicus brief, the Court expressed "reluctan[ce] to do so when the issue is one of first impression involving the interpretation of a federal statute on which the Department of Justice expressly declines to take a position. ${ }^{356}$ Since Davis, the Supreme Court has not heard a federal criminal case in which Miranda issues were presented. This leaves the opinions in that case as the Court's last words on the subject. The next Part reviews the law of sua sponte consideration to determine whether, when next presented with a case potentially implicating Section 3501, the Court should follow Justice Scalia's suggestion.

\section{THE JUdicial POWER TO CONSIDER ARgUMENTS NOT RAISED BY PARTIES}

It is well settled that "[w]hen an issue or claim is properly before the court, the court is not limited to the particular legal theories advanced by the parties, but rather retains the independent power to identify and apply the proper construction of governing law. ${ }^{357}$ This power is best understood by examining three main contexts in which it is used: (1) when the court lacks subject matter jurisdiction; (2) when the court wishes to apply a nonjurisdictional doctrine of judicial restraint; and (3) when the court disagrees with the manner in which the parties have characterized the legal issues.

"Id.

ss Id at $457 \mathrm{n}$ * (majority opinion). The Court was referring to an amicus brief filed by the Washington Legal Foundation. Id.

${ }^{s}$ Id. Interestingly, Justice Scalia joined the majority opinion in its entirety. Read literally, it is not inconsistent with his view. The majority simply indicated that it was "reluctant" to consider the statute sua sponte, and Justice Scalia agreed that "the refusal to consider arguments not raised is a sound prudential practice." Id at 464 (Scalia concurring). Likewise, all Justices agreed that sua sponte consideration of the statute would be inappropriate in Davis. It is possible that, despite their footnote, the other signers of the majority opinion (Chief Justice Rehnquist, and Justices O'Connor, Kennedy, and Thomas) share Justice Scalia's view that the statute should be considered sua sponte at some point in the future. Note that four Justices (Souter, Blackmun, Stevens, and Ginsburg) concurred in the judgment with an opinion that did not mention Section 3501; they have given no indication of their views on the subject.

${ }^{37}$ Kamen $v$ Kemper Financial Services, Inc, 500 US 90, 99 (1991). 


\section{A. Subject Matter Jurisdiction}

The most frequent occasion for the sua sponte consideration of legal issues is also the least controversial. Subject matter jurisdiction has always been treated as an issue that cannot be waived, and federal courts have often raised it on their own. ${ }^{58}$ Indeed, not only may courts raise jurisdictional defects sua spontethey have an obligation to do so. ${ }^{59}$ This duty is a product of the constitutional dimensions of limited federal jurisdiction, ${ }^{60}$ and of the principle that the constitutional limitations on the jurisdiction of the federal courts reflect a limitation on the power of the federal government. ${ }^{61}$ Private litigants cannot enlarge the Constitution's grant of power by consenting to the exercise of jurisdiction where it does not exist. In this respect, subject matter jurisdiction differs from requirements such as personal jurisdiction, which exist to protect the due process rights of litigants and are therefore waivable. ${ }^{62}$

Sua sponte consideration of jurisdictional issues takes two forms. The first involves cases in which a basic jurisdictional requirement is lacking. For example, the parties might claim to be of diverse citizenship, or they might agree that their case presents a federal question. The court may examine these stipulations on its own initiative. If it disagrees with the assertions of the parties, it must dismiss the case for lack of jurisdiction. ${ }^{63}$

${ }^{83}$ As early as 1804, it was established that the doctrines of estoppel and waiver do not apply to subject matter jurisdiction. See Capron $v$ Van Noorden, 6 US (2 Cranch) 126, 126 (1804). In that case, the plaintiff, appealing from a judgment for the defendant, obtained a reversal by pointing out a defect in the jurisdictional allegations of his own pleadings. Id at 127. See also Louisville and Nashville Railroad Co v Mottley, 211 US 149, 150 (1908) (raising subject matter jurisdiction sua sponte); Liberty Mutual Insurance Co $v$ Wetzel, 424 US 737, 740 (1976) (same).

${ }^{59}$ Mt. Healthy City School District Board of Education $v$ Doyle, 429 US 274, 278 (1977) (noting that "we are obliged to inquire sua sponte whenever a doubt arises as to the existence of federal jurisdiction"). See also Mansfield, $C \& L M$ Railway Co $v$ Swan, 111 US 379,382 (1884) (noting the existence of an "inflexible" rule that "without exception" requires the Court, on its own motion, to determine if jurisdiction is lacking).

${ }^{60}$ The jurisdiction of federal courts extends only to the classes of disputes specified in US Const, Art III, § 2. Of course, the jurisdiction of lower federal courts is further limited by the terms of jurisdictional statutes, enacted pursuant to the congressional power to "constitute Tribunals inferior to the supreme Court," id at Art I, \& 8, and the Necessary and Proper Clause, which permits Congress to make rules for those tribunals, id at Art I, $\S 10$.

${ }^{61}$ See Insurance Corporation of Ireland, Ltd $v$ Compagnie des Bauxites de Guinée, 456 US 694, 702 (1982) (Subject matter jurisdiction "contributes to the characterization of the federal sovereign.").

${ }^{\approx}$ See id at $703 \mathrm{n} 10$.

${ }^{*}$ See, for example, Louisville \& Nashville Railroad, 211 US at 154 (finding no federal question); Mansfield, C \& L M Railway Co, 111 US at 381 (finding no diversity). 
The second form involves cases in which no "case or controversy" is presented. ${ }^{64}$ Article III allows courts to determine only "actual controversies arising between adverse litigants" and prevents a court from issuing a "judgment [that] could not be executed, and [that would] amoun[t] in fact to no more than an expression of opinion. ${ }^{165}$ If courts lacked the power to look behind the parties' presentation of a case, then "litigants, by agreeing on the legal issue presented, [could] extract the opinion of a court on hypothetical Acts of Congress or dubious constitutional principles, an opinion that would be difficult to characterize as anything but advisory. ${ }^{.66}$ Thus, on its own motion, the Supreme Court has found jurisdiction to be lacking in cases where the parties seek an abstract determination of the validity of a statute, ${ }^{67}$ where the parties seek a decision based on a hypothetical state of facts, ${ }^{68}$ or where the controversy between the parties is not yet ripe for adjudication. ${ }^{69}$

The Supreme Court recently addressed the need for courts to consider unraised issues in United States National Bank of Oregon $v$ Independent Insurance Agents of America, Inc. ${ }^{70}$ In that case, a bank sought to sell insurance through its branch in a small town. The bank obtained permission to do so from the Comptroller of the Currency pursuant to 12 USC § 92, which authorizes banks to act as insurance agents in towns with a population of less than five thousand..$^{71} \mathrm{~A}$ group of insurance

* US Const, Art III, $\S 2$. The first case recognizing the prohibition on giving advisory opinions appears to have been Hayburn's Case, 2 US (2 Dall) 408 (1792). The next year, the Justices declined a request from President Washington and Secretary of State Jefferson to render advice on legal issues related to American relations with France. See Richard H. Fallon, Jr., Daniel J. Meltzer, and David L. Shapiro, Hart and Wechsler's the Federal Courts and the Federal System 92-93 (Foundation 4th ed 1996) (reprinting the correspondence between Jefferson and the Court).

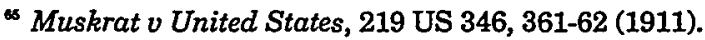

* United States National Bank of Oregon v Independent Insurance Agents of America, Inc, 508 US 439, 447 (1993).

"See Texas $v$ Interstate Commerce Commission, 258 US 158, 162 (1922). See also Nashville, Chattanooga \& St. Louis Railway v Wallace, 288 US 249, 262 (1933), citing Muskrat, 219 US at 361-62.

${ }^{*}$ See Nashville, Chattanooga \& St. Louis Railway, 288 US at 262, citing Liberty Warehouse Co v Grannis, 273 US 70, 73 (1927) (declining to hear a declaratory judgment action in which the plaintiffs sought the invalidation of a statute but did not allege that they had done or contemplated doing any of the acts prohibited by it).

* See Blanchette v Connecticut General Insurance Corp, 419 US 102, 138 (1974) ("[B]ecause issues of ripeness involve, at least in part, the existence of a live 'Case or Controversy,' we cannot rely upon concessions of the parties and must determine whether the issues are ripe for decision in the 'Case or Controversy' sense.") (footnote omitted).

${ }^{70} 508$ US 439 (1993). This case provides the Supreme Court's most extensive recent discussion of the sua sponte power.

${ }^{71}$ Id at $441-43$. See also Act of Sept 7, 1916, 39 Stat 753, codified at 12 USC $\S 92$ 
agents challenged the Comptroller's decision, asserting that it was based on a misreading of the statute. ${ }^{72}$ The district court granted summary judgment for the bank, finding that the Comptroller's decision was authorized by the statute. ${ }^{73}$ On its own motion, the D.C. Circuit observed that there was some doubt as to whether the statute had been repealed and directed the parties to address the question of the statute's continuing validity. ${ }^{74} \mathrm{Al}$ though the parties agreed that the statute was still in effect, the court nonetheless proceeded to consider the question. It ultimately concluded that the statute had been repealed and decided for the insurance agents on that basis. ${ }^{75}$

The D.C. Circuit held that sua sponte determination of the statute's continued existence was not merely permissible, but mandatory. ${ }^{76}$ The opinion did not make explicit the relationship between the court's duty to consider the statute and the prohibition of advisory opinions. However, in an opinion concurring in the denial of rehearing en banc, the judges who constituted the panel majority explained:

[B]y declining to argue that Congress repealed the section, appellants cannot stipulate into existence a repealed statute and then compel the court to compliantly advise the parties what it would do if the statute existed.

I am convinced that it is within the Court's power to determine the existence of a statute essential to the determination of a case or controversy whether or not the parties assume or stipulate that the statute does or does not exist. At bottom, I do not think it within the power of the Court to render an advisory opinion on the construction of a statute

(1994).

${ }^{72}$ Independent Insurance Agents, 508 US at 443-44.

3 Id at 444.

${ }^{7}$ Id. See also Independent Insurance Agents of America $v$ Clarke, 955 F2d 731, 733 (DC Cir 1992).

${ }^{75}$ Independent Insurance Agents, $955 \mathrm{~F} 2 \mathrm{~d}$ at 733-39. The statute was originally enacted in 1916, but two years later, it was omitted from a recodification of the section of the Revised Statutes that contained it: Despite this omission, it was included in the 1934, 1940, and 1946 editions of the United States Code. Beginning in 1952, it was omitted, with a note stating that it had been repealed in 1918. Congress, however, apparently assumed that it was still in effect, and amended it during the 1980s. See Independent Insurance Agents, 508 US at 441-43.

${ }^{76}$ Independent Insurance Agents, 955 F2d at 734 ("Because this controversy hangs on the interpretation of a statute that is presumed not to exist, we not only have the right to inquire into its validity, we have the duty to do so."). 
whose existence depends on the failure of the parties to assert its invalidity. ${ }^{77}$

The Supreme Court endorsed the action of the D.C. Circuit, finding that sua sponte consideration of the statute's continued existence was proper. ${ }^{78}$ The Court declined, however, to address the lower court's conclusion that it had a duty to raise the issue. ${ }^{79}$

The rule suggested by the D.C. Circuit in Independent Insurance Agents may go too far. If courts had a duty to consider, sua sponte, any potentially dispositive argument not raised by the parties, then they would have to raise issues on their own motion much more frequently than they currently do. For example, they might no longer be able to invoke the doctrine of waiver: if an improperly presented argument were potentially dispositive, the court would need to consider it anyway in order to avoid giving an advisory opinion. It may be for this reason that the Supreme Court later described as "questionable" the D.C. Circuit's conclusion that there was a duty to consider the statute in Independent Insurance Agents. ${ }^{80}$

Because the advisory opinion concept is so ill-defined, it is difficult to devise a rule that describes exactly what kinds of arguments courts are obliged to consider sua sponte. ${ }^{81}$ Nevertheless, it is safe to say that there are many cases in which the prohibition of advisory opinions obliges courts to consider arguments sua sponte, and there are many other cases in which courts have discretion (but not a duty) to do so.

7 Independent Insurance Agents of America, Inc $v$ Clarke, 965 F2d 1077, 1078 (DC Cir 1992) (Sentelle concurring in the denial of rehearing en banc). Dissenting from the original decision, Judge Silberman suggested that the question of the validity of the statute was not jurisdictional, and he indicated that he believed the majority agreed. Independent Insurance Agents, $955 \mathrm{~F} 2 \mathrm{~d}$ at 741-42 (Silberman dissenting). The quoted language from Judge Sentelle's concurrence in the denial of rehearing en banc, which the judges from the original panel majority joined, seems to contradict this assessment.

${ }^{38}$ Independent Insurance Agents, 508 US at 448 . While the Supreme Court reversed the D.C. Circuit, it did so because it disagreed with the conclusion that the statute had been repealed. Id at 462-63.

79 Id at 448 ("We need not decide whether the Court of Appeals had, as it concluded, a 'duty' to address the status of section 92 (which would imply error in declining to do so), for the court's decision to consider the issue was certainly no abuse of its discretion.").

${ }^{\infty}$ Describing its opinion in Independent Insurance Agents, the Court noted that it "declines even to brush aside the Court of Appeals' (questionable) contention that there was 'a "duty" to address the status of section 92,' . . . " Lebron v National Railroad Passenger Corp, 513 US 374, 383 n 3 (1995).

${ }^{\text {s }}$ It is not necessary to devise such a rule here. There has been no support for the argument that courts are obliged to consider Section 3501 sua sponte. See note 119 and accompanying text. 


\section{B. Nonjurisdictional Doctrines of Judicial Restraint}

Jurisdiction is not the only issue that courts will consider sua sponte; courts will often raise nonjurisdictional doctrines of judicial restraint on their own motion. These doctrines include ripeness (which is sometimes jurisdictional but can also be prudential) and the principle that courts should decide cases on nonconstitutional grounds whenever possible. Because these issues are not jurisdictional, courts are not required to raise them sua sponte. Accordingly, when deciding whether to raise a nonjurisdictional issue sua sponte, courts will often weigh these doctrines against other prudential considerations that counsel against going beyond the arguments raised by the parties. ${ }^{82}$

Under the ripeness doctrine, courts will not adjudicate a controversy until it is sufficiently well developed to merit judicial resolution. For example, courts will not review an administrative action before its effects have been "felt in a concrete way by the challenging parties. ${ }^{\text {} 83}$ This doctrine is based both on jurisdictional limitations and on prudential reasons for declining to decide cases where there is jurisdiction..$^{84}$ Even in cases where the ripeness issues are not jurisdictional, courts may consider them sua sponte. ${ }^{85}$ This is not surprising, as ripeness, like jurisdiction, serves a goal other than protecting the rights of the parties: it protects the interests of the court itself. However, unlike the limits imposed by jurisdiction, the limits of the ripeness doctrine are created by courts (to the extent that the doctrine is prudential); therefore courts are free to ignore them if they choose to do so.

Courts also adhere to the principle that they should avoid constitutional adjudication when possible. ${ }^{86}$ This too is a doctrine of judicial restraint. The doctrine is not intended to safeguard the rights of litigants; rather, it protects the judiciary and the other. branches of government by avoiding unnecessary conflicts between the courts and the legislature. "[T] mine whether to exercise that restraint and cannot be bound by the wishes of the parties." ${ }^{37}$ Thus, the principle is often invoked

${ }^{2}$ See Part II.D.

* Reno v Catholic Social Services, Inc, 509 US 43, 57 (1993), quoting Abbott Laboratories $v$ Gardner, 387 US 136, 148-49 (1967).

See Catholic Social Services, 509 US at 57 n 18.

${ }^{\infty}$ See id.

${ }^{85}$ See, for example, Clinton $v$ Jones, 117 S Ct 1636, 1642 \& n 11 (1997). See also Ashwander $v$ Tennessee Valley Authority, 297 US 288, 347 (1936) (Brandeis concurring) ("The Court will not pass upon a constitutional question although properly presented by the record, if there is also present some other ground upon which the case may be disposed of.").

${ }^{87}$ Blanchette $v$ Connecticut General Insurance Corp, 419 US 102, 138 (1974). 
sua sponte. ${ }^{88}$ However, because it is not jurisdictional, courts are not obliged to invoke the principle if they have prudential reasons not to do so. ${ }^{89}$

\section{Disagreement with the Parties' Characterization of Legal Issues}

The most interesting instances of sua sponte consideration occur when there is no jurisdictional question or doctrine of restraint at issue, but when the court simply disagrees with the parties' characterization of the legal issues underlying their dispute. In these cases, sua sponte consideration of an issue is purely discretionary. While the exercise of the power is a matter of judicial discretion, the cases clearly establish that the power does exist.

\section{The leading cases.}

By the end of the nineteenth century, the Supreme Court recognized that "[t]here can be no estoppel in the way of ascertaining the existence of a law," for "the question as to the existence of a law is a judicial one. ${ }^{~} 90$ Early this century, in Swift \&

See, for example, Boynton $v$ Virginia, 364 US 454 (1960) (deciding the case on statutory grounds even though the petition for certiorari presented only a constitutional question); Meredith Corp v FCC, 809 F2d 863, 872 (DC Cir 1987) (opinion by Silberman) ("Normally, we would not consider an argument not properly raised by the parties .... But here another even more important principle of judicial restraint weighs upon us. Federal courts traditionally have sought to avoid constitutional questions if at all possible ... and this constitutional question, as we have noted, has particularly far reaching implications.”). Judge Silberman's support for sua sponte consideration of nonconstitutional arguments is odd in light of his comments in Independent Insurance Agents: "I agree with appellants' implicit premise: that unless we determine the validity question to be jurisdictional, we should not decide it." 955 F2d at 741-42 (Silberman dissenting); "Since the question is not jurisdictional, we do not see how it can be appropriate for a federal court, sua sponte, to decide it ... ." Independent Insurance Agents, 965 F2d at 1079 (Silberman dissenting from the denial of rehearing en banc). The avoidance of constitutional questions is not a jurisdictional requirement. See note 89.

Of course, Judge Silberman's comments in Independent Insurance Agents were probably not meant as a general statement on the consideration of arguments not raised by parties; they were directed to the statutory issue in that case, where no constitutional issues were present. Notice that in National Treasury Employees Union v United States, Judge Silberman, in dissent, cited both Meredith and the Supreme Court's opinion in Independent Insurance Agents to support the proposition that the case should be decided on a statutory basis that was not argued by the parties. 3 F3d 1555, 1562 (DC Cir 1993) (Silberman dissenting).

* See Zobrest $v$ Catalina Foothills School District, 509 US 1, 8 (1993) ("WW]e think the prudential rule of avoiding constitutional questions has no application [here]. The fact that there may be buried in the record a nonconstitutional ground for decision is not by itself enough to invoke this rule.").

" Town of South Ottawa $v$ Perkins, 94 US 260, 267-68 (1874). South Ottawa was not, strictly speaking, about consideration of an argument that was not raised by the parties. 
Co $v$ Hocking Valley Railway $\mathrm{Co}^{91}$ the Court established that courts are not obliged to accept party stipulations on issues of law. In that case, the Hocking Valley Railway sought to collect demurrage charges for railroad cars used by Swift. ${ }^{92}$ The parties had stipulated that the cars were on private track, and Swift argued that the demurrage rules, approved by the Interstate Commerce Commission, were unreasonable as applied to cars on private track..$^{93}$ The Court rejected the stipulation, observing that "[i]f the stipulation is to be treated as an agreement concerning the legal effect of admitted facts, it is obviously inoperative; since the court cannot be controlled by agreement of counsel on a subsidiary question of law. . $^{\text {9 }}$

Swift might be considered merely a case about advisory opinions, similar to the cases refusing to render judgment on a hypothesized state of facts. ${ }^{95}$ However, two features of the case suggest that it actually stands for the broader proposition that courts are never bound by party concessions on issues of law. First, the statement that stipulations of law are inoperative is not supported by a citation to federal cases discussing the case or controversy requirement; instead, it is supported by state cases asserting the broad proposition described above. ${ }^{96}$ Second, the

In the case, the plaintiff was a holder of bonds issued by the defendant town pursuant to a state statute that apparently authorized the sale of the bonds. The plaintiff argued that the town was estopped from arguing that the authorizing statute had not been properly enacted (because its passage by the Illinois Senate had not been entered in the Senate's journal). It was this argument that the Court rejected. Id at 261-63, 266-67.

The case is relevant here because its language has a broader significance than the facts that gave rise to the case. It has been cited by later courts in support of the proposition that courts have an independent power to determine what law applies to a case, even when that determination is contrary to party stipulations. See, for example, Independent Insurance Agents, $955 \mathrm{~F} 2 \mathrm{~d}$ at 733.

1243 US 281 (1917).

22 Id at 284.

${ }^{23}$ Id at 284-85.

2 Id at 289. Based on its own examination of the record, the Court concluded "that the track in question was not a 'private track." Id at 286.

${ }^{2}$ See id at 290 ("If the stipulation is to be treated as an attempt to agree "for the purpose only of reviewing the judgment below, that what are the facts shall be assumed not to be facts, a moot or fictitious case is presented."). Compare Liberty Warehouse Co $v$ Grannis, 273 US 70, 74 (1927) ("[Jurisdiction] does not extend to the determination of abstract questions or issues framed for the purpose of invoking the advice of the court without real parties or a real case.").

${ }^{\circ}$ Swift, 243 US at 289 n 1, citing, for example, San Francisco Lumber Co v Bibb, 139 Cal 325, 326, 73 P 864, 865 (1903) ("When a particular legal conclusion follows from a given state of facts, no stipulation of counsel can prevent the court from so declaring it."); Owen v Herzikoff, 2 Cal App 622, 624, 84 P 274, 275 (1906) ("The stipulation . . . being a stipulation as to an erroneous interpretation of the legal effect of the contract, should be disregarded."). 
Swift case has been repeatedly cited by federal courts in contexts where there is no advisory opinion issue. ${ }^{97}$

More recently, two Supreme Court decisions have reaffirmed the principle that courts have an independent power to decide what principles of law are relevant to the case, even when doing so requires consideration of arguments not raised by the parties. In Arcadia $v$ Ohio Power $\mathrm{Co}^{98}$ the parties had agreed on the questions presented by the case. The Court, however, found that there was "another question antecedent to these and ultimately dispositive of the present dispute. ${ }^{n 99}$ The Court decided the case on the basis of its answer to that question, which was neither considered by the court below nor addressed by either party. ${ }^{100}$ The following year, in Kamen $v$ Kemper Financial Services, ${ }^{101}$ the Court cited Arcadia for the proposition that "[w] hen an issue or claim is properly before the court, the court is not limited to the particular legal theories advanced by the parties, but rather retains the independent power to identify and apply the proper construction of governing law. ${ }^{102}$ Together, these cases demonstrate that courts have the power to consider an argument not raised by the parties if judges find that consideration of the argument is necessary in order to decide the case correctly. ${ }^{103}$

${ }^{97}$ See, for example, Sanford's Estate v Commissioner, 308 US 39, 51 (1939) (citing Swift for the proposition that courts "are not bound to accept, as controlling, stipulations as to questions of law"); King $v$ United States, 641 F2d 253, 258 (5th Cir 1981) (citing Swift in rejecting a stipulation purporting to allocate the burden of proof).

498 US 73, 77 (1990).

$\infty$ Id.

${ }^{100}$ Id at 86 (Stevens concurring).

${ }^{101} 500$ US 90 (1991).

${ }^{102}$ Id at 99, citing Arcadia, 498 US at 77.

${ }^{100}$ Both Arcadia and Kemper were cited with approval in Independent Insurance Agents, 508 US at 446-47.

Even though Independent Insurance Agents involved sua sponte consideration of an issue that may have had the potential to make the case moot, the case has been repeatedly cited in support of the broader proposition that courts may consider any issue sua sponte. See, for example, Colorado Republican Federal Campaign Committee v Federal Election Commission, $116 \mathrm{~S}$ Ct 2309, 2319 (1996) (plurality opinion) (citing Independent Insurance Agents for the proposition that "we are not bound to decide a matter of constitutional law based on a concession by the particular party before the Court as to the proper legal characterization of the facts"); United States $v$ Price, 75 F3d 1440, 1443-44 (10th Cir 1996) (citing Independent Insurance Agents to reject the defendant's suggestion that "if the government responds to a suppression motion based on state law by arguing only the state law issue, then state suppression law, rather than the Fourth Amendment, controls. ... [T] he government [could not,] by its argument, require a federal court to ignore the Fourth Amendment"). 


\section{Justifications for the exercise of the power.}

When judges consider an issue sua sponte because they do not think the parties' arguments are adequate, they rarely state their specific reasons for doing so. Nevertheless, they seem to have in mind the concept to which Justice Scalia referred when he discussed "the Third Branch's obligation to decide according to the law."104 The courts enjoy the power "to say what the law is," which entails a power to say so correctly. ${ }^{105}$ Judge Easterbrook has made this point more explicitly, observing that "litigants' failure to address the legal question from the right perspective does not render us powerless to work the problem out properly. A court of appeals may and often should do so unbidden rather than apply an incorrect rule of law to the parties' circumstances."106

Judge Easterbrook's observation reflects the fact that courts are properly concerned with more than just the interests of litigants. The adjudication of cases generates precedents and clarifies the law, providing benefits to everyone in society. ${ }^{107}$ The precedent-generating function of courts is inhibited when courts defer to parties' incorrect statements of the law rather than declare which legal principles in fact govern the case. ${ }^{108}$ Moreover, courts have a valid interest in preserving their own institutional prestige and legitimacy, both of which are reduced when courts decide cases based on incorrect principles of law.

\section{A special case.}

Because courts are never required to consider a nonjurisdictional issue sua sponte, their decision to do so will depend on a weighing of prudential factors. There is a special case, though, in which a heightened interest in considering the issue makes sua

${ }^{10}$ Davis, 512 US at 465 (Scalia concurring). Of course, to refer to an "obligation" is to put the argument too strongly; sua sponte consideration is truly obligatory only when the issue in question is jurisdictional. See Part II.A.

${ }^{100}$ Marbury v Madison, 5 US (1 Cranch) 137,.177 (1803).

${ }^{106}$ Williams-Guice $v$ Board of Education of the City of Chicago, 45 F3d 161, 164 (7th Cir 1995) (emphasis added), citing Independent Insurance Agents, 508 US at 444-48.

${ }^{107}$ See Steven Shavell, The Fundamental Divergence Between the Private and the Social Motive to Use the Legal System, 26 J Legal Stud 575, 579 (1997) ("[A] private-social divergence plainly may exist with respect to other social benefits of use of the legal system, too, such as ... the elaboration of the law through its interpretation and the setting of precedent.").

${ }^{108}$ Consider the Court's observations in Young $v$ United States, 315 US 257, 259 (1942): "The public interest that a result be reached which promotes a well-ordered society is foremost in every criminal proceeding. . . . Furthermore, our judgments are precedents, and the proper administration of the criminal law cannot be left merely to the stipulation of parties." 
sponte consideration more frequent. Courts will sometimes consider overruling a prior decision even if no party has requested it. ${ }^{109}$ In such a case, it might be wise for a court, sua sponte, to request that the parties brief the issue of whether the precedent should be overruled. In the absence of such encouragement, even a party that would benefit from an overruling may be reluctant to request it, particularly in light of the high probability of losing by virtue of stare decisis. Instead, the party may argue that its position is consistent with the prior decision. ${ }^{110}$ Thus, the normal presumption that parties will make all of the relevant arguments is weakened. Sua sponte consideration of the need to overrule precedent may be necessary to promote the development of the law.

\section{Prudential Concerns Counseling Against Sua Sponte Consideration of Arguments}

After examining the often expansive rhetoric of opinions justifying the judicial power to consider arguments not raised, it might be surprising to find that such consideration is not more frequent. In practice, it is unusual for courts to consider issues sua sponte; it is rarer still when the issue is not jurisdictional. As Justice Scalia conceded in Davis, "the refusal to consider arguments not raised is a sound prudential practice. ${ }^{111}$ Understanding the infrequency of sua sponte consideration requires an examination of the prudential concerns to which Justice Scalia was referring.

Ironically, the most commonly cited statement that courts should consider only the arguments made by parties comes from then-Judge Scalia: "The premise of our adversarial system is that appellate courts do not sit as self-directed boards of legal inquiry and research, but essentially as arbiters of legal questions presented and argued by the parties before them."112 Three policies support the traditional refusal of courts to consider arguments not raised.

\footnotetext{
${ }^{100}$ See Izumi Seimitsu Kogyo Kabushiki Kaisha v US Phillips Corp, 510 US 27, 33 (1993), citing Blonder-Tongue Laboratories, Inc $v$ University of Illinois Foundation, 402 US 313, 319-21 (1971).

${ }^{110}$ See, for example, Blonder-Tongue Laboratories, 402 US at 319 (noting that both parties in that case had filed briefs arguing against the overruling of Triplett $v$ Lowell, 297 US 638 (1936), but that the Court considered the issue anyway after it was raised in an amicus brief by the United States).

" 512 US at 464 (Scalia concurring).

${ }^{112}$ Carducci $v$ Regan, 714 F2d 171, 177 (DC Cir 1983).
} 
First, when an issue is considered sua sponte, parties lack notice that it will be raised. ${ }^{113}$ This may be unfair to litigants (and potential intervenors or amici) who may see the case decided against them based on an argument that they had no chance to rebut. ${ }^{114}$ Unfairness to litigants, though, is not the only danger created when the parties are unaware of the theory on which the case will be decided. The court suffers as well; when the parties have not briefed the issue, the court is less likely to understand the issue thoroughly. ${ }^{115}$

Second, sua sponte consideration of issues is an inefficient use of judicial resources. Courts are able to save time by relying on litigants to present arguments in cases. They can then focus their energies on evaluating these arguments. If they routinely sought to identify what they perceived to be the relevant legal issues and to develop their own arguments, they would lose this benefit.

Third, it may be unseemly for a court actively to seek out its own issues to consider. ${ }^{116}$ This is perhaps what then-Judge Scalia

${ }^{113}$ This concern seems to be especially important to courts. It is emphasized in Yee $v$ City of Escondido, 503 US 519, 535-36 (1992), in a discussion of the related issue of Supreme Court Rule 14.1(a), which provides that the Court will only consider questions presented in the petition for certiorari. The Court noted:

Were we routinely to consider questions beyond those raised in the petition, the respondent would lack any opportunity in advance of litigation on the merits to argue that such questions are not worthy of review ... [and] would face the formidable task of opposing certiorari on every issue the Court might conceivably find present in the case.

Id.

In cases where courts do consider an argument not raised by the parties, they often emphasize that the parties have been given adequate notice. See, for example, Davis, 512 US at 463 (Scalia concurring) ("This is not the first case in which the United States has declined to invoke $\S 3501$ before us-nor even the first case in which that failure has been called to its attention."); Teague $v$ Lane, 489 US 288, 300 (1989) (considering an issue raised only by an amicus, but pointing out that "that question is not foreign to the parties").

${ }^{114}$ See, for example, Independent Insurance Agents, 955 F2d at 744 (Silberman dissenting) ("Injustice is-more likely to result from our reaching the issue than from our declining to do so, because the question of section 92 's validity affects many entities, including members of the insurance and banking industries who have relied on the law's continued existence and who, having no notice that the question might be decided, had no opportunity to make their views known in this case.").

${ }^{115}$ Note, though, that all of the concerns arising from lack of notice are mitigated in cases where the court directs briefing on an issue prior to deciding the case on that basis.

${ }^{116}$ One might argue that such behavior is not only unseemly but impermissible, because it could cause the court to reach an issue on which the parties have no disagreement, thus violating the case or controversy requirement. This argument is flawed, however, because the judicial power "is the right to determine actual controversies arising between adverse litigants, duly instituted in courts of proper jurisdiction." Muskrat $v$ United States, 219 US 346, 361 (1911). As long as the parties disagree on the ultimate outcome of the litigation, that is, as long as the suit represents the "pursuance of an honest and ac- 
meant when he referred to "the premise of our adversarial system," thereby inviting comparison to other systems in which judges are much more active. ${ }^{117}$ The legitimacy of the antimajoritarian power of judicial review, for example, depends in part on the fact that judges typically exercise the power only as it is necessary to decide disputes between litigants. This legitimacy could be eroded if judges were perceived as pursuing their own agendas by seeking out issues to consider. Viewed in this way, the refusal to make sua sponte consideration a routine practice is an important doctrine of judicial restraint.

\section{APPLYING THE DOCTRINE OF SUA SPONTE CONSIDERATION TO SECTION 3501}

Almost by definition, a court cannot rely on a bright line test in order to decide whether to invoke a discretionary and prudential practice such as sua sponte consideration. Instead, a court's decision depends on how it weighs the particular factors present in each case. In the case of Section 3501, this weighing must begin with an analysis of how the factors discussed in Part II apply to the statute.

The threshold question is whether the applicability of Section 3501 is a jurisdictional issue. If it is, then sua sponte consideration of the statute would be mandatory. It might appear that the statute's existence does affect courts' jurisdiction: perhaps the statute removes the necessary case or controversy. After all, if the statute is constitutionally valid and reverses Miranda, then by declining to apply it, courts confront issues that "might be entirely irrelevant under federal law," making the opinions they render on those issues purely advisory. ${ }^{118}$

This argument, however, is incorrect. ${ }^{119}$ Miranda issues arise in the context of criminal litigation: the requisite case or controversy comes from the adverse relationship between the government and the criminal defendant, and the admissibility of a con-

tual antagonistic assertion of rights by one [party] against another," the requisite controversy is present. Independent Insurance Agents, 508 US at 446, quoting Muskrat, 219 US at 359.

${ }^{117}$ Carducci, 714 F2d at 177. See also United States v Burke, 504 US 229, 246 (1992) (Scalia concurring) ("The rule that points not argued will not be considered is more than just a prudential rule of convenience; its observance, at least in the vast majority of cases, distinguishes our adversary system of justice from the inquisitorial one.").

${ }^{\text {"Davis, }} 512$ US at 465 (Scalia concurring).

${ }^{119}$ Appropriately, it seems to have attracted no support. Justice Scalia does not endorse it; if he did, he would have insisted that the Court consider Section 3501 in Davis itself, not in some future case. See id at 464 (agreeing with the majority that sua sponte consideration was not appropriate in Davis). 
fession is simply one of many issues that must be considered in determining criminal liability. Whether or not a court considers Section 3501, the underlying controversy will still exist. In this respect, Section 3501 differs from 12 USC § 92, the statute at issue in Independent Insurance Agents. Had Section 92 not existed, the question of whether the Comptroller's regulations comported with the statute would have ceased to exist. ${ }^{120}$ Section 3501 is different because it concerns an evidentiary issue subsidiary to the main issue of criminal liability; therefore, the Court has correctly concluded that there is no obligation to consider it sua sponte.

Another argument in favor of judicial consideration of Section 3501 is that it might enable the Court to avoid unnecessary constitutional adjudication. Miranda issues are constitutional in nature; therefore, in every case where the Court interprets the Miranda doctrine, it makes constitutional law. Relying on the statute might permit the Court to avoid this obligation. However, two features of the statute weaken this argument. First, it applies only to federal cases. Even if the Court did use Section 3501, it would still have to confront Miranda issues in state criminal cases; the statute would not greatly reduce the amount of constitutional adjudication that the Court had to undertake. Second, because the statute is itself of doubtful constitutionality, consideration of the statute would force the Court to confront a difficult constitutional issue. The doctrine of avoidance of constitutional adjudication thus does not provide a very good argument for sua sponte consideration of Section 3501.

The best argument for sua sponte consideration of Section 3501 is based on the judicial obligation to decide cases according to the law. This principle is of special relevance in the context of Section 3501, which plainly sets out rules for courts to use in determining whether to admit confessions. When courts ignore these rules because neither party asks that they be followed, the resulting opinions feel artificial. As Justice Scalia put it, "[1]egal analysis of the admissibility of a confession without reference to these provisions is equivalent to legal analysis of the admissibility of hearsay without consulting the Rules of Evidence; it is an unreal exercise."121

In addition, Section 3501 presents a factor that traditionally heightens courts' willingness to consider arguments not raised by the parties. The statute may require Miranda to be overruled (at

\footnotetext{
${ }^{220}$ See Independent Insurance Agents, 965 F2d at 1078 (Sentelle concurring in the denial of rehearing en banc).

${ }^{121}$ Davis, 512 US at 463 (Scalia concurring).
} 
least in the federal context), and courts have been willing to overrule precedent sua sponte. ${ }^{122}$ Such willingness enables the law to evolve even when parties are reluctant to ask that precedents be overruled.

In the context of Section 3501, the traditional prudential arguments against sua sponte consideration of issues are weak, at least as applied to cases after Davis. First, no litigant can complain of a lack of notice that the statute might be considered. It has already been discussed at oral argument before the Supreme Court. ${ }^{123}$ Furthermore, Justice Scalia's concurrence in Davis has alerted all litigants to the possibility that the Court might consider it. In addition, the Court can easily address concerns about notice by directing the parties to brief the issue before the Court decides it. Likewise, concerns about judicial economy are misplaced. The issues raised by Section 3501 are not hidden, because the statute is unambiguous and its applicability is clear. The Court will not have to expend much effort to seek them out. Indeed, to the extent that the statute can reduce the number of Miranda cases the Court must consider, consideration of the statute could actually promote judicial economy.

The final prudential argument against sua sponte consideration of the statute is that it would not comport with the traditional role of courts in an adversarial system. But the adversarial system does not require that courts be purely passive evaluators of legal propositions advanced by the parties. Instead, courts retain the power to make their own determinations of what the law is; this power is itself a traditional (and necessary) part of the adversary system. ${ }^{124}$ If any case is appropriate for the exercise of that power, it must be one in which the parties fail to mention a statute that clearly dictates the result.

${ }^{12}$ See text accompanying notes 109-10.

${ }^{123}$ See note 38.

${ }^{124}$ See United States $v$ Burke, 504 US 229, 246 (1992) (Scalia concurring) ("[T]here must be enough play in the joints that the Supreme Court need not render judgment on the basis of a rule of law whose nonexistence is apparent on the face of things, simply because the parties agree upon it."). See also United States $v$ Pryce, 938 F2d 1343, 1348 (DC Cir 1991) (opinion by Williams) ("Only if one adopts an absolutist approach to the adversary system can one contend that courts must never address unargued issues, no matter how obvious their proper resolution may be."). 


\section{DO SEPARATION OF POWERS CONCERNS PROVIDE AN ARGUMENT AGAINST SUA SPONTE CONSIDERATION OF SECTION 3501?}

The analysis in Part III leaves out a peculiar characteristic of Section 3501 that might be relevant to the question of whether to consider it sua sponte. The party declining to raise the statute is no ordinary litigant; it is the executive branch of the government, and it is pursuing a criminal prosecution. Traditionally, courts accord great deference to the executive's decisions about the exercise of prosecutorial powers. Might this mean that it is inappropriate for courts to force the executive to use a statute that it does not want to use in its criminal prosecutions? An understanding of the separation of powers issues posed by Section 3501 must begin with an exploration of the executive power to initiate and to terminate prosecutions. Ultimately, though, sua sponte consideration of the statute presents an issue that is not truly analogous to either power. Thus, courts are not obliged to defer to the executive by declining to consider Section 3501.

\section{A. Initiation of Prosecutions}

In general, the executive has unreviewable discretion to decide whether or not to prosecute a violation of a criminal statute. It has long been the rule that "[p]ublic prosecutions, until they come before the court to which they are returnable, are within the exclusive direction of the district attorney."125 Whether to charge a defendant, and what charges to bring, are questions within the prosecutor's discretion. ${ }^{126}$ This rule is based on the constitutional principle of separation of powers. ${ }^{127}$ Prosecutorial decisions are "the special province of the Executive Branch, inasmuch as it is the Executive who is charged by the Constitution

${ }^{125}$ Confiscation Cases, 74 US 454, 457 (1868).

${ }^{128}$ United States $v$ Batchelder, 442 US 114, 124 (1979). See also United States $v$ Nixon, 418 US 683,693 (1974) ("[T]he Executive Branch has exclusive authority and absolute discretion to decide whether to prosecute a case.").

The discretion of the prosecutor is subject to the constraint of nondiscrimination: the executive may not selectively enforce laws based on "an unjustifiable standard such as race, religion, or other arbitrary classification." Oyler $v$ Boles, 368 US 448, 456 (1962). See also Batchelder, 442 US at 123-25. This constraint is not relevant in the Section 3501 context, where the executive's refusal to invoke the statute has been both nondiscriminatory and helpful to defendants.

${ }^{127}$ To some extent, it has a statutory basis as well. Prosecutorial discretion is part of the legal background against which Congress legislates; when it enacts a criminal statute, it does so with the understanding that the executive may elect to prosecute only some of the people whose conduct falls within its terms. 
to "take Care that the Laws be faithfully executed."128 Because prosecutorial discretion is constitutionally committed to the executive, courts generally may not order the executive to prosecute an individual for a crime. ${ }^{129}$

Of course, prosecutorial discretion per se is not at issue in the Section 3501 context. In a case involving Section 3501, the executive is prosecuting a defendant, not refraining from doing so. The executive has merely failed to call to the court's attention a potentially relevant statute governing the admissibility of evidence. Considering such a statute sua sponte in the context of a prosecution begun by the executive is substantially different from initiating a prosecution. Thus, the executive power to choose the subjects of prosecution does not provide a bar against sua sponte consideration of Section 3501.

\section{B. Termination of Prosecutions}

At common law, the prosecutor's decision to terminate a prosecution, like the decision to initiate one, was unreviewable. ${ }^{130}$ Today, Rule 48(a) of the Federal Rules of Criminal Procedure provides that the Attorney General or the U.S. Attorney "may by leave of court file a dismissal of an indictment, information or complaint and the prosecution shall thereupon terminate. ${ }^{1131}$ The requirement of judicial approval is intended primarily to protect defendants from governmental harassment. ${ }^{132}$ Without such a rule, the government might dismiss a case just before jeopardy attached, only to refile later. ${ }^{133}$

${ }^{228}$ Heckler $v$ Chaney, 470 US 821, 832 (1985), quoting US Const, Art II, § 3.

${ }^{220}$ Inmates of Attica Correctional Facility v Rockefeller, 477 F2d 375, 379-82 (2d Cir 1973). See also United States $v$ Cox, 342 F2d 167, 172 (5th Cir 1965) (en banc) (holding that a U.S. Attorney may not be compelled by the court to sign an indictment prepared by a grand jury).

The one exception to the rule that courts may not order prosecutions arises in the context of contempt proceedings. See Young $v$ Vuitton et Fils SA, 481 US 787 (1987). In that case, the trial judge appointed an attorney as a special prosecutor to prosecute a contemner. Although the Supreme Court held that the prosecution and resulting convictions were invalid because the attorney selected was an interested party, it sustained the trial court's power to appoint a special prosecutor: "The ability to punish disobedience to judicial orders is regarded as essential to ensuring that the Judiciary has a means to vindicate its own authority without complete dependence on other Branches. ... Courts cannot be at the mercy of another Branch in deciding whether such proceedings should be initiated." Id at 796.

${ }^{130}$ See, for example, Confiscation Cases, 74 US at 457 (explaining that the U.S. Attorney "may enter a nolle prosequi at any time before the jury is empanelled for the trial of the case, except in cases where it is otherwise provided by some act of Congress").

${ }^{131}$ FRCrP 48(a).

12 United States $v$ Hamm, 659 F2d 624, 628 (5th Cir 1981).

${ }^{23}$ Jeopardy attaches when a jury is impaneled and sworn. See Crist $v$ Bretz, 437 US 
When a defendant does not oppose a motion to dismiss, courts accord great deference to the prosecutor's decision. The decision will be disturbed only "in those extraordinary cases where it appears the prosecutor is motivated by considerations clearly contrary to the manifest public interest." ${ }^{134}$ Such considerations must be truly egregious, such as when the prosecutor has accepted a bribe or when his decision to dismiss is based on personal dislike for the victim of the crime. ${ }^{135}$ Indeed, some courts have even suggested that a district court may never have the discretion to deny an uncontested motion to dismiss. ${ }^{136}$

In Rinaldi $v$ United States, ${ }^{137}$ the Supreme Court held that a prosecutor could use Rule 48(a) to dismiss an indictment even after a defendant had been convicted. ${ }^{138}$ In that case, the defendant had participated in a robbery and was convicted on both state and federal charges. ${ }^{139}$ While such dual prosecution is constitutionally permissible under the "dual sovereign" exception to the Double Jeopardy Clause, ${ }^{140}$ it violates the Justice Department's Petite policy. ${ }^{141}$ The Court noted that the policy protects the same interests as the constitutional protection against double jeopardy, and concluded that "the federal courts should be receptive, not circumspect, when the Government seeks leave to implement that policy."

The reasoning in Rinaldi suggests an analogy to Section 3501. In Rinaldi, the Court supported the government's effort to protect a defendant beyond his judicially defined constitutional rights. One might conclude that courts should be similarly sup-

28, 35 (1978); Downum v United States, 372 US 734, 736 (1963).

${ }^{134} \mathrm{Hamm}, 659 \mathrm{~F} 2 \mathrm{~d}$ at 628. See also United States $v$ Cowan, $524 \mathrm{~F} 2 \mathrm{~d}$ 504, 513 (5th Cir 1975) ("The exercise of [executive] discretion with respect to the termination of pending prosecutions should not be judicially disturbed unless clearly contrary to manifest public interest.").

${ }^{135}$ See United States $v$ Smith, 55 F3d 157, 159 (4th Cir 1995).

${ }^{136}$ See Rinaldi $v$ United States, 434 US 22, 29 n 15 (1977) (per curiam) (reserving the issue of whether district courts have such discretion); United States $v$ Gonzalez, 58 F3d 459,461 (9th Cir 1995) (noting that the issue remains open).

${ }^{137} 434$ US 22 (1977) (per curiam).

${ }^{138}$ Id at 25 \& $n 8$.

${ }^{130}$ Id at 23.

${ }^{140}$ See Bartkus v Illinois, 359 US 121 (1959); Abbate $v$ United States, 359 US 187, 193 95 (1959).

${ }^{141}$ Rinaldi, 434 US at $24 \&$ n 5. See also Petite $v$ United States, 361 US 529, 530-31 (1960) (describing the policy).

${ }^{142}$ Rinaldi, 434 US at 29 . The Court was not unanimous in its conclusion that courts should be receptive to prosecutorial withdrawal of an indictment after conviction. See id at 32-34 (Rehnquist dissenting); Watts v United States, 422 US 1032, 1036-37 (1975) (Burger dissenting) ("The federal courts have no role in prosecutorial decisions, but, once the judicial power has been invoked, it is decidedly the role of federal courts to interpret the decisions of this Court and to assess the validity of judgments duly entered."). 
portive of the government's effort to protect Miranda rights even after they have been limited by statute.

While this analogy has a certain intuitive appeal, ultimately it is not persuasive. When a court allows a prosecutor to dismiss a case after a conviction has been obtained, the court is simply facilitating the exercise of prosecutorial discretion; the end result is the same as if no prosecution had been brought. ${ }^{143}$ In contrast, when courts defer to a prosecutor's failure to raise an argument, they may be forced to confront legal issues that they might otherwise have avoided. Worse yet, they are forced to decide the case according to principles that may be incorrect, a practice that damages judicial credibility. It does not follow from the proposition that the executive has discretion in beginning and ending prosecutions that the executive has the right "to determine what objections to admissibility of [a] confession are valid in law. ${ }^{\$ 144}$

\section{Conduct of Prosecutions}

The analysis above suggests that there is a fundamental difference between control over whether to begin or end a prosecution and control over what arguments may be considered when the prosecution is carried on in court. The former is committed exclusively to the executive. The latter, however, is generally within the domain of the judiciary; the executive branch has no more power than any other litigant to bind the court to its stipulations. Moreover, the judicial power to consider unasserted arguments is no different in criminal cases than in other kinds of cases. An appellate court, for example, may raise the issue of harmless error sua sponte even when the government has failed to argue it. ${ }^{145}$

The distinction between the initiation of prosecutions and the conduct of prosecutions reflects the fact that the congressional understanding of a criminal statute differs from that of a procedural statute. When Congress enacts a criminal statute, it does so

${ }^{163}$ Indeed, even in the absence of a power to dismiss, the executive could achieve the same results through exercise of "the Power to grant Reprieves and Pardons for Offenses against the United States." US Const, Art II, \& 2.

${ }^{14}$ Davis, 512 US at 465 (Scalia concurring).

${ }^{145}$ See, for example, United States v Giovannetti, 928 F2d 225, 227 (7th Cir 1991) (per curiam) (identifying "the length and complexity of the record, whether the harmlessness of the error or errors found is certain or debatable, and whether a reversal will result in protracted, costly, and ultimately futile proceedings in the district court" as factors to be considered in determining whether to raise harmless error sua sponte); United States $v$ Pryce, 938 F2d 1343, 1348 (DC Cir 1991) (opinion by Williams) (adopting the analysis of Giovanetti); id at 1351 (Randolph concurring) (emphasizing the mandatory language of the harmless error rule in FRCrP 52(a)); Lufkins v Leapley, 965 F2d 1477, 1482 (8th Cir 1992) 
with the knowledge that the executive need not prosecute every person who falls within its terms, and in fact may choose never to prosecute anyone. In contrast, when it enacts a procedural statute to guide the courts, Congress does not intend for the executive branch to be able to nullify the statute through a wholesale refusal to invoke it. ${ }^{146}$ Even though the executive has exclusive control over whether to bring a prosecution, it does not control what law is to be applied during the prosecution.

\section{CONCLUSION}

Our adversary system normally relies on litigants to frame the legal issues presented to courts. It is usually prudent for courts to avoid considering arguments not raised, thus ensuring fair notice to litigants, preventing waste of limited judicial resources, and avoiding an appearance of judicial overreaching. Nevertheless, courts retain a power to consider issues sua sponte if doing so is necessary to decide the case correctly. While the exercise of this power is most common when the issue involved is jurisdictional, it is by no means limited to that context.

In federal cases presenting Miranda issues, courts should consider the applicability of Section 3501 sua sponte. To refrain from doing so is to refrain from deciding the case according to the law. By avoiding consideration of the statute, courts do not significantly advance any of the policies traditionally associated with the refusal to consider arguments not raised, nor do they promote values associated with separation of powers. While the executive has the discretion to initiate and to terminate prosecutions, it is for the judiciary to decide what legal arguments will be considered in a case.

("We undertake harmless error analysis sua sponte in this case because we find that reviewing the rather straightforward record will prevent an expensive and futile remand."). But see Pryce, 938 F2d at 1354 (Silberman dissenting in part) ("If the government refuses to argue [harmless error], I do not see how the court can sua sponte raise the issue without encroaching into the executive branch's prosecutorial prerogatives.").

${ }^{146}$.Thus, Justice Scalia noted that "Section 3501 of Title 18 is a provision of law directed to the courts." Davis, 512 US at 464 (Scalia concurring). 